\title{
Brexit and dentistry
}

\author{
E. Sinclair, ${ }^{* 1}$ S. Stagnell ${ }^{2}$ and S. Shah ${ }^{3}$
}
IN BRIEF
- Gives a brief history of the EU and the policies affecting dentistry.
- Provides insight into the recent trends of dental professional migration to the UK.
- Informs of the implications of professional migration on dental workforce planning in the UK.
- Reflects on the impact of both remaining in and exiting from the EU.

On 23 June 2016, eligible UK voters will be asked to decide whether to vote in the EU referendum. The EU impacts on our daily lives in more ways than many people realise. Dentistry is affected by EU legislation. Examples include the movement of dental professionals, the import of dental equipment and materials, as well as health and safety legislation. Many more EU dentists and DCPs come to the UK to work than vice versa. These numbers have increased markedly since 2004. The result of the vote may affect how dentistry operates in the UK in future years. In addition, a vote to stay would not necessarily prevent change. There are attempts underway to increase the ease by which professionals can work in other member states, especially on a temporary basis. This too is likely affect dentistry at some point. Workforce planners and policy makers should factor in the impact of the EU in future dental policy.

\section{INTRODUCTION}

To say that discussions of the forthcoming EU referendum are au courant would be an understatement. Now that there is a definitive date set for the referendum ${ }^{1}$ of 23 June 2016 , the concept of 'Brexit' is one that consumes both many column inches and personal conversation. Beyond the wider implications on day-to-day life, it is worth considering the potential impact on the dental profession. Like anything concerning withdrawal from the EU, the situation is multifaceted and more complex than at first glance. There are potential implications for both the existing and future dental workforce of the country. Whatever the outcome, there must be a greater focus on workforce planning in the UK which will take into account movements of professionals across international borders. An apolitical view is presented here, examining the current arrangements for dentistry and the scenarios that could materialise in the short to medium term following any vote.

1Dental Core Trainee in Dental Public Health, Health Education England (HEE); ${ }^{2}$ Clinical Fellow in Leadership and Management, NHS England and HEE; ${ }^{3}$ Consultant in Dental Public Health and Training Programme Director *Correspondence to: E. Sinclair

Email: esinclair@kss.hee.nhs.uk

\section{Refereed Paper}

Accepted 4 May 2016

DOI: 10.1038/sj.bdj.2016.371

${ }^{\circledR}$ British Dental Journal 2016; 220: 509-512

\section{BACKGROUND}

The United Kingdom originally joined the early incarnation of the EU (the European Community or Common Market) in 1973. ${ }^{2}$ This was confirmed by popular consent in the referendum of $1975 .^{3}$ At the time, the organisation consisted only of Western European countries. Greece joined in 1981, followed by Portugal and Spain in 1986. The 1990s saw the addition of Austria, Sweden and Finland. Finally, many of the countries of Eastern Europe joined in two batches 2004 (8 countries) and 2007 (Bulgaria and Romania). The last country to join was Croatia in 2013.

\section{LEGISLATIVE FRAMEWORK}

The EU directive (PQD) 2005/36 EC (recently $^{4}$ incorporated into UK law ${ }^{5}$ ) on the recognition of professional qualifications for dentists, allows dentists to freely work in other member states subject to approval by the local competent authority; in the case of the UK, that is the GDC. The term EEA (European Economic Area) includes the countries of Norway, Iceland and Lichtenstein who have similar rights of access but are not EU members. The terms EU and EEA are used interchangeably here.

\section{CURRENT TRENDS}

EU dentists working in the UK is nothing new, ${ }^{6}$ but has increased markedly since 2004 .
Data from the GDC (Table 1) demonstrate notable increases that occurred in the five years prior to 2011, with 2015 figures for comparison. It indicates that the six member states which are providing the largest numbers of dentists in descending order are: Poland, Sweden, Spain, Greece, Ireland, and Romania. Some key points to note are that Malta has 20\% of its dentists already registered with the GDC. The large numbers of Swedish trained dentists arrived in the period approximately between 1995-2004.

\section{PHASES OF DENTAL MIGRATION}

The following are rough estimates of the periods of dental migration that have affected the UK market.

\section{Phase 1 (pre-1995)}

Very small numbers of EU dentists came to the UK, mainly from other Western European countries. The main overseas trained workforce originated from new and old Commonwealth countries (for example, India, Australia and South Africa).

\section{Phase 2 (1995-2004)}

A few hundred Swedish and Danish trained dentists, many of Middle Eastern origin registered and began practising in the UK. Automatic recognition of Commonwealth BDS degrees ended for dentists qualifying after 1 January 2001. 
Table 1 Non-UK EEA qualified dentists by country and year of first GDC registration (as at 31 December of registration year). 2015 GDC figures courtesy of Professor K. A. Eaton (personal communication) ${ }^{7}$

\begin{tabular}{|c|c|c|c|c|c|c|}
\hline Country & 2007 & 2008 & 2009 & 2010 & 2011 & 2015 \\
\hline Austria & 3 & 5 & 4 & 5 & 4 & 3 \\
\hline Belgium & 53 & 51 & 51 & 49 & 46 & 33 \\
\hline Bulgaria & 45 & 116 & 167 & 243 & 300 & 319 \\
\hline Czech Republic & 48 & 62 & 84 & 90 & 104 & 164 \\
\hline Denmark & 131 & 128 & 127 & 127 & 131 & 115 \\
\hline Estonia & 17 & 16 & 16 & 14 & 15 & 15 \\
\hline Finland & 40 & 34 & 36 & 36 & 33 & 22 \\
\hline France & 82 & 82 & 78 & 82 & 78 & 92 \\
\hline Germany & 474 & 477 & 475 & 466 & 439 & 317 \\
\hline Greece & 419 & 449 & 466 & 509 & 579 & 671 \\
\hline Hungary & 146 & 187 & 202 & 249 & 264 & 340 \\
\hline Iceland & 3 & 2 & 4 & 2 & 2 & 1 \\
\hline Ireland & 661 & 652 & 625 & 684 & 721 & 661 \\
\hline Italy & 117 & 148 & 158 & 182 & 192 & 275 \\
\hline Latvia & 22 & 28 & 38 & 57 & 66 & 63 \\
\hline Lithuania & 105 & 102 & 127 & 148 & 162 & 191 \\
\hline Malta & 31 & 37 & 33 & 34 & 35 & 28 \\
\hline Netherlands & 49 & 52 & 50 & 51 & 49 & 37 \\
\hline Norway & 37 & 36 & 40 & 37 & 36 & 27 \\
\hline Poland & 848 & 872 & 849 & 847 & 849 & 803 \\
\hline Portugal & 216 & 272 & 338 & 407 & 447 & 507 \\
\hline Romania & 155 & 255 & 344 & 460 & 554 & 625 \\
\hline Slovakia & 39 & 46 & 46 & 45 & 43 & 46 \\
\hline Slovenia & 0 & 1 & 0 & 1 & 3 & 2 \\
\hline Spain & 281 & 288 & 390 & 538 & 640 & 683 \\
\hline Sweden & 996 & 988 & 980 & 968 & 925 & 770 \\
\hline Switzerland & 12 & 15 & 10 & 7 & 5 & 6 \\
\hline
\end{tabular}

\section{Phase 3 (2004-2007)}

Eight eastern European countries join the EU. The main countries from which dentists migrated to the UK were Poland and the Baltic states.

\section{Phase 4 (2007-2014)}

Romania and Bulgaria provided the main source of dentists migrating to the UK. The Eurozone crisis may have contributed to a large increase in dentists from Spain and Greece seeking work in the UK.

\section{SCENARIO 1: THE UK VOTES TO REMAIN}

Should the outcome of a vote be to remain in the EU, things would probably stay pretty much as they are now:
- Dentists would be free to move around the EU with minimal difficulties in registering

- The UK would retain the flexibility to recruit healthcare staff from other EU member states to fill shortages where required. There is a large labour pool which, due to the absence of an EU wide 'numerus clausus' means that many member states will remain net exporters of healthcare professionals such as dentists

- UK graduates will potentially have the opportunity to take advantage of initiatives such as the European Professional Card. ${ }^{8}$ Whilst this has not yet extended to dentistry, it is an electronic scheme aimed at helping professionals move country more easily, especially for short periods. Notably it has an alert system, which is aimed at alerting competent authorities about individuals for whom there may be patient safety concerns

- Safety initiatives (originating from EU directives) such as the Sharp Instruments in Healthcare Regulations 2013 (UK) which have banned recapping of sharps would continue to be implemented

- Europe wide sustainability initiatives such as the phasing down of amalgam and recycling of waste electricals would continue

- The UK would continue to benefit from cross border patient safety initiatives such as the ability to use other EU dental laboratories and the knowledge that equipment will have been certified safe due to the presence of CE marking.

The EU requires the UK to implement public health initiatives ${ }^{9}$ such as the Tobacco Products Directive which helps in the fight against smoking - a serious concern for the dental profession. There is no suggestion that any of the above features will necessarily disappear after withdrawal from the EU, but this will clearly depend on negotiations.

\section{SCENARIO 2: THE UK VOTES TO LEAVE THE EU}

Assuming that the UK votes to leave the European Union in June 2016, there would be a two year period of negotiation under Article 50 of the Lisbon Treaty. ${ }^{10}$ By definition, it is impossible to be certain of what would follow. Here we explore hypothetical scenarios and outcomes.

One aspect that colours this whole argument is the fate of the existing EU directive on mutual recognition of qualifications and freedom of movement. The underlying question revolves around whether they would be scrapped entirely or kept in some limited form? The likelihood is, that if some form of freedom of movement remains for workers in a post Brexit economy, then logically some form of mutual recognition would have to stay also. Below are some possible scenarios that the UK could adopt. They are based on arrangements that currently exist between non-EU counties (Table 2) and may provide a basis for a future framework.

It is likely that those EU dentists already here will be unaffected. Under the Vienna Convention on the Law of Treaties (VCLT), ${ }^{11}$ previous treaty rights must be respected. Therefore, in terms of immigration status, they are likely to be given permanent residency and their previously recognised qualifications will continue to be eligible for 
registration in the same way Commonwealth dentists pre-2001 are. In addition, the UK is likely to keep existing arrangements in place until the end of the second year (or more) of the negotiation period. However, one source of uncertainty would be dentists who registered before, but whose registration has since lapsed. Would they be able to re-register without exams post Brexit? One assumption is that post Brexit, assuming there is no longer freedom of movement, qualifications that previously were eligible for registration would now be subject to ORE and pose complicated circumstances to navigate: For example, a Polish dentist obtains a visa and wants to work as a dentist here. Would their qualification be honoured or would they need to sit the ORE?

Irish dentists pose a particular challenge. They would be EU dentists but also free to travel and work here as part of the Common Travel Area. This arrangement predated the EU. The assumption would be that special provision would have to be made to treat them effectively as UK graduates for the purpose of regulation of dentistry. Irish nationals have never been considered foreign under UK law. The Republic of Ireland is likely to have many UK dentists working there. Their future status would have to be resolved. In the context of the above, the chances are the

\begin{tabular}{|c|c|c|c|c|c|c|}
\hline Arrangement & None & $\begin{array}{l}\text { Legacy } \\
\text { arrangement }\end{array}$ & $\begin{array}{l}\text { Trans-Tasman } \\
\text { (Aus/NZ } \\
\text { agreement) }\end{array}$ & EEA & $\begin{array}{l}\text { North American } \\
\text { Free Trade } \\
\text { Agreement } \\
\text { (NAFTA) }\end{array}$ & $\begin{array}{l}\text { Swiss-EU } \\
\text { agreement }\end{array}$ \\
\hline Example & $\begin{array}{l}\text { India } \rightarrow \\
\text { UK }\end{array}$ & $\begin{array}{l}\text { Australia } \rightarrow \\
\text { UK }\end{array}$ & $\begin{array}{l}\text { Australia } \rightarrow \\
\text { New Zealand }\end{array}$ & $\begin{array}{l}\text { Norway } \rightarrow \\
\text { UK }\end{array}$ & Canada $\rightarrow$ US & $\begin{array}{l}\text { EU } \rightarrow \\
\text { Switzerland }\end{array}$ \\
\hline $\begin{array}{l}\text { Mutual } \\
\text { recognition } \\
\text { of BDS/DDS? }\end{array}$ & $\begin{array}{l}\text { No, ORE } \\
\text { required }\end{array}$ & $\begin{array}{l}\text { Yes, pre } 2001 \\
\text { graduates. } \\
\text { Otherwise } \\
\text { ORE required }\end{array}$ & Yes & Yes & $\begin{array}{l}\text { Partial-depending } \\
\text { on state }\end{array}$ & Yes \\
\hline $\begin{array}{l}\text { Work visa } \\
\text { required? }\end{array}$ & Yes & Yes & No & No & $\begin{array}{l}\text { No, if professional } \\
\text { with job offer }\end{array}$ & $\begin{array}{l}\text { No, but some } \\
\text { restrictions } \\
\text { possible from } \\
2017\end{array}$ \\
\hline
\end{tabular}

Table 3 Numbers of DCPs and where they qualified. Table reproduced from ref. 13, General Dental Council

\begin{tabular}{l|l|l}
\hline Title & UK qualified & Qualified outside UK \\
\hline Clinical dental technician & 234 & 0 \\
\hline Dental hygienist & 6,013 & 320 \\
\hline Nurse & 50,496 & 151 \\
\hline Dental technician & 6,131 & 189 \\
\hline Dental therapist & 2,215 & 15 \\
\hline Orthodontic therapist & 322 & 1 \\
\hline Total & 65,411 & 676
\end{tabular}

likely outcome is minimal disturbance, but a 'nightmare scenario' would be that these individuals would have to cease practice and return to the UK. As with many EU directives, the onus is on the member state to implement it locally. If one member state decided to place complex bureaucratic process in the way of existing UK dentists practising, this would cause difficulty.

Dentists from the EU may no longer be eligible for the waiver on Foundation Training and this could potentially pose a further barrier to working in the NHS. They would need to undergo equivalence training to obtain a performer number. This is a more difficult route given the shortage of places and lack of defined schemes.

EU directives may no longer need to be implemented. As small businesses, this could potentially reduce administrative burden on dental practice. For example, the Health and Safety at Work Framework Directive $(89 / 391 / \mathrm{EEC})^{12}$ requires risk assessments to be kept in writing regardless of the risk.

Beyond the impact on dentists we must also consider the impact on the wider dental team and whether DCP recruitment (for example, dental nurses) could be affected if mutual recognition of qualifications were scrapped. Information from the GDC (Table 3) would suggest this is unlikely, given the comparatively low numbers of those registered with qualifications from outside the UK.

\section{IMPLICATIONS FOR WORKFORCE PLANNING}

Up to this point, there has been the option of EU labour to supplement the workforce strategy. For several years, new entrants to the GDC register from outside the UK (mostly $\mathrm{EU})$ have been greater in number than those from UK dental schools. ${ }^{14}$ In the event of Brexit, this could result in EU dentists finding it much more difficult to work in the UK market. Essentially, this would mean UK graduates would once again form the vast majority of the future dental workforce. However, assuming EU dentists already here choose to remain, there is already a considerable oversupply in many areas of the country. They may then choose to leave or relocate to underserved areas such as Wales and the South West of England. In broad terms, Brexit could potentially make workforce planning more straightforward in terms of undergraduate numbers. It could also result in a shift in the dentist job market, with fewer potential dentists, this could impact on the supply curve for dentists available.

Another change would be that UK graduates, forming the majority of the new incoming workforce would all be fluent in English 
and would have studied dentistry within a GDC curriculum. One of the difficulties of EU movement is the language barrier, cultural differences in dealing with patients, as well as difference in clinical skills. On the other hand, ensuring that future applicants to the register from outside the UK complete a GDC approved examination could assist in achieving uniformity of standards.

However, there could be potential disadvantages to this new strategy. UK graduates may still gravitate towards urban areas which could pose a problem in recruiting dentists to remote rural locations. As a result, we could experience the labour shortages that occurred in the late 1990s and early 2000s. Ultimately, regardless of whether EU dentists remain able to come and go freely, incentives will still be necessary to encourage clinicians to work and remain in less desirable locations.

\section{CONCLUSION}

The decision to vote for UK exit from the EU ('Brexit') is matter for each individual voter. However, whether or not the UK leaves or remains, the decision will affect the dental profession in a number of ways; should we face leaving the EU, there will be many important aspects to consider. Government policy makers need to factor any decision into future workforce planning and in particular the number of training places for dental professionals.

1. HM Government. European Union Referendum Act 2015. London: United Kingdom Parliament, 2015. Available online at http://www.legislation.gov.uk/ ukpga/2015/36/pdfs/ukpga_20150036_en.pdf (accessed May 2016)

2. HM Government. European Communities Act 1972. United Kingdom: Parliament, 1972. Available online at http://www.legislation.gov.uk/ukpga/1972/68/ pdfs/ukpga_19720068_en.pdf (accessed May 2016).

3. House of Lords. Referendums in the United Kingdom Report with Evidence. HL Paper 9. Clerk of the Select Committee on the Constitution, 2009. Available from: http://www.publications.parliament.uk/pa/ld200910/ Idselect/Idconst/99/99.pdf (accessed May 2016).

4. European Commission. Evaluation of the Professional Qualifications Directive. pp 309-317. Directorate General Internal Market and Services Brussels: European Commission, 2011.

5. HM Government. European Union (Recognition of Professional Qualifications) Regulations 2015. 2015. Available online at https://www.gov.uk/government/uploads/system/uploads/attachment_data/ file/417461/bis-15-253-draft-statutory-instrument-eu-recognition-of-professional-qualifications-regulations-2015.pdf (accessed May 2016).

6. Patel R, Eaton K A, Garcia A, Rincon V, Brooks J. An investigation into the numbers of dentists from 19 European Economic Area (EEA) member states currently registered to work in the United Kingdom and key differences between the practise of dentistry in the UK and their member states of origin. Br Dent J 2011; 211: 133-137.

7. Eaton K, Angela Garcia R P and V R. A practical resource to help in the support of non-UK, EEA qualified dental practitioners practising in the UK. 2012.

8. European Commission. European Professional Card-European Commission. Single Market and Standards. 2016. Available online at http:// ec.europa.eu/growth/single-market/services/ free-movement-professionals/policy/european-professional-card/index_en.htm.

9. McKee M, Galsworthy M J. Brexit: a confused concept that threatens public health. J Pub Health 2016; 38: 3-5

10. Official Journal of the European Union. Treaty of Lisbon amending the Treaty on European Union and the Treaty establishing the European Community. 2007/C 306/01 2007.

11. United Nations. Vienna Convention on the Law of Treaties. United Nations Treaty Series 1980; 1155: 331-512.

12. European Agency for Safety and Health at Work. Directive 89/391/EEC- OSH 'Framework Directive'- Safety and health at work- EU-OSHA. 1989. Available online at https://osha.europa.eu/en/legislation/directives/the-osh-framework-directive/1 (accessed May 2016).

13. General Dental Council. Annual report and accounts 2013 [Internet]. London; 2013. Available online at https://www.gdc-uk.org/Newsandpublications/Publications/Publications/GDC AR 2013 FINAL WEB.pdf (accessed May 2016).

14. Batchelor P. Oral health and the EU referendum. $\mathrm{Br}$ Dent J 2015; 219: 513. 